\title{
Varieties of Indigeneity in the Americas*
}

\author{
Edward Telles \\ University of California Santa Barbara \\ and \\ Florencia Torche \\ Stanford University
}

Contact Information:

Edward Telles. Department of Sociology, Social Sciences and Media Studies (SSMS) 3423, University of California Santa Barbara (UCSB), Santa Barbara CA 93106-9430.

Email: etelles@ucsb.edu

Florencia Torche. Department of Sociology Stanford University, 450 Serra Mall Building 120 McClatchy Hall \# 422, Stanford CA 94305. Email: torche@stanford.edu.

* The authors thank Andrew Penner, Charles Hale, Emiko Saldivar Tanaka and four anonymous reviewers for insightful feedback. 


\title{
Varieties of Indigeneity in the Americas
}

\author{
Abstract \\ We examine sources of indigenous identity in the two countries with the largest indigenous \\ populations in the Western Hemisphere - Mexico and Peru. We find that the size of the indigenous \\ population varies dramatically depending on the measure of indigeneity used, and that using \\ multiple measures captures distinct modes of indigeneity. Using latent class analysis, we find that \\ contemporary indigenous classification clusters around four types, which we characterize as \\ Traditional Indians, Indigenous Mestizos, New Indians, and Non-Indigenous. Traditional Indians \\ tend to be indigenous on virtually all indicators and they are especially poor, dark, and rural. \\ Indigenous Mestizos tend to speak an indigenous language but self-identification as indigenous is \\ tenuous. New Indians assert an indigenous identity despite their frequent lack of linguistic \\ knowledge and close indigenous ancestry and they are as urban, educated and light-skinned as the \\ Non-Indigenous. The analysis addresses sociological concepts of ethnic boundaries, assimilation, \\ mestizaje and symbolic ethnicity and discusses the implications of distinct modes of indigenous \\ ethnicity.
}




\section{Varieties of Indigeneity in the Americas}

Although ethnic boundaries are fluid in the real world, states strictly define ethnic groups through their censuses on the basis of one or two questions. By creating ethnic categories, such as indigenous, states estimate its population composition but also shape shape representations of the nation and its identity (Loveman 2014; Wimmer 2013). Throughout the Americas, censuses have been the main source of knowledge about who indigenous people are, how many there are, where and how they live and the extent of ethno-racial inequality, and they have been the main source of information for the design of public policies. Classifying indigenous people has represented an essentialization project of defining "real Indians" (Forte 2013; Field 1994; Deloria 1969), whether it be through visible forms of difference, community, ancestry or language. In recent years, with growing recognition of minority rights and indigenous movements, censuses in democratic states have begun to incorporate the views of indigenous leaders, academics and international NGOs, often establishing self-identification as a new criterion for ethnic classification (Forte 2013; Loveman 2014; Lucero 2013). The diverse ways of classification have led to a multiplicity of ways to define, count, and target the indigenous population across countries in the Americas.

Censuses tend to rely on one or at most two indicators of ethnicity. By the 2000 round of censuses, most Latin American countries used self-identification criteria, in various forms, while language has long been used in some countries (del Popolo and Oyarce 2005, Villarreal 2014). Instead of treating these diverse indicators as mutually-exclusive and attempting to determine which one is the most appropriate to capture a presumably fixed demographic group, we hypothesize that the use of several measures may reveal distinct modes of indigeneity, suggesting that people may be indigenous on some dimensions but not necessarily others. Through an empirical procedure, we examine patterns of classification to discover three primary clusters of indigenous classification in Mexico and Peru. Although varieties of indigeneity have been discussed

by prior research (Wasserstrom 1983; Eschbach, Supple and Snipp 1998; De la Cadena 2003), there 
has been no systematic analysis of indigenous types in Latin America or, as far as we know, of particular ethnic types anywhere. We ask: how do specific measures capture particular aspects or dimensions of indigeneity? What are the implications of diverse measures for assessing the size of the indigenous population? What can multiple measures tell us about different types of indigeneity? This examination of variation in indigenous ethnicity also addresses important sociological questions such as: how much ethnic fluidity is there? What are its sources? Is assimilation or mestizaje a one-way process? Can indigenous ethnicity be symbolic?

\section{Theoretical background: Ethnicity, Assimilation, and Mestizaje}

Language and self-identification reflect distinctions based on culture and identity, and remit to underlying theoretical conceptions of ethnicity and ethnic boundaries. Prior to 1969, anthropologists understood ethnic differences as delimited by a set of fixed cultural traits. Barth (1969) would transform this notion by arguing that ethnicity is socially constructed and that ethnic boundaries emerge out of a social process in which individuals may choose or be classified in particular categories. More recently, Wimmer (2013), examining a variety of cases globally, finds that in ethnic boundary-making, self-identity and classification by others are important, as are the cultural or physical traits that we associate with a particular ethnic category.

For Latin America, the reliance on language to classify the indigenous since the nineteenth century reflects cultural understandings of ethnicity; self-identity emerged in recent decades, particularly since the International Labor Organization's Convention 169 (Indigenous Peoples Convention), promulgated in 1989. Both forms of classification were largely coterminous but their overlap is decreasing as fluency in indigenous languages declines across the region (Abrams and Strogatz 2003; Walsh 2005). Many children of indigenous language speakers continue to identify as indigenous but are no longer fluent in an indigenous language (Barbary and Martinez Casas 2016); 
at the same time, many indigenous language speakers do not identify as indigenous (de la Cadena 2003; Martinez Novo 2006).

In Latin America, debates about who is indigenous have often been based on some combination of modernization and assimilation theories, often expressed as mestizaje (racial mixing), an elite-led ideology that glorified the region's history of race blending. By becoming modern, often by learning Spanish and moving to urban areas (not only by race mixing), indigenous people may assimilate by becoming mestizo (De la Cadena 2003; Rosemblatt 2018). The mestizaje ideology holds that mestizos (mixed race persons) constitute a cultural and a racial synthesis that epitomizes the normative national identity to which indigenous people can assimilate to. Thus, indigenous is a malleable cultural (and racial) status that is not strictly based on phenotypic or ancestry rules. The mestizo category thus blurs the lines between mixed-race people and the constituent "races" of white, indigenous and black (although the black was ignored or downplayed in ideas of mestizaje in much of Latin America) (Sue and Golash-Boza 2009). While promoting the mestizo as modern and quintessentially national, mestizaje ideologies tend to denigrate the indigenous as backward, although associated with a glorious past. Although indigenous people who live in indigenous communities, speak indigenous languages, and maintain indigenous cultural traits are clearly considered indigenous, many others straddle and cross the indigenous/mestizo boundary (de la Cadena 2003; Telles and PERLA 2014).

One might think of indigenous identity as existing on a continuum from the least to the most assimilated, where the former is indigenous by virtually any indicator while the latter bears some markers or sense of self as indigenous but they are considered mestizo or non-indigenous by others. To use a concept from U.S. sociology, their self-reported ethnicity might be considered symbolic in the sense that it has little or no consequence for their everyday behavior or their life chances but it allows them a sense of social-rootedness in a community (Gans 1979, Waters 1990). 
Mestizaje ideologies continue to guide racial/ethnic classification in many Latin American countries (Telles and PERLA 2014) but the (re-)emergence of indigenous social movements, a recent transition to official multiculturalism, and the recognition of indigenous rights may provide fertile ground for new indigenous identities, even in a context of persistent stigmatization. At the same time, the number of indigenous language speakers has been rapidly declining, undermining what has been the primary marker of indigenous identity in the past (Villarreal 2014). Thus, indigenous identity seems to be in flux, presenting new challenges in identifying and enumerating that population and, more generally, complicating the question of who is indigenous.

\section{The Indigenous in Latin America}

Indigenous classification is fluid in Latin America (Belote and Belote 1984; Moreno 2014; Telles and Paschel 2014), as in the United States (Eschbach, Supple and Snipp 1998; Nagel 1997), whether classification is based on putative, genetic or social criteria. National censuses of the nineteen Latin American countries estimate the indigenous population of the region at 40.3 million people (23.3 million of them in Mexico and Peru) or 7.3\% of the Latin American population (Telles and PERLA 2014). In countries like Mexico and Peru, where most of the population arguably has indigenous ancestry, indigenous classification is rarely based on ancestry, as in the blood-quantum rules used in the United States (Rosemblatt 2018). Rather, following ILO Convention 169, Latin American countries now use self-identification (del Popolo and Oyarce 2005).

In Mexico, where the indigenous past is central to national identity, establishing who is indigenous has been an important task since its independence (Bonfil Batalla 1996; Martinez Casas et al. 2014). While the Census has used language as the official defining indicator since the nineteenth century, anthropologists have been deeply aware of the complexities of indigenous classification and have long grappled with alternative approaches for identifying indigenous people (Rosemblatt 2018). In the 1930s and 1940s, anthropologists debated the relative importance of 
criteria such as culture, race, and consumption patterns in defining who was indigenous, sometimes devising elaborate criteria or even degrees of indigeneity (Rosemblatt 2018). A 1950 Mexican Census publication poses the following question:

“...before anything else, who is an Indian? The person whose features look it but he cannot speak an indigenous language, doesn't live like an aboriginal or feel that way? A person who speaks a native language but doesn't appear autochthonous or live like an indigenous person? Or one who feels like an Indian even though he doesn't look like one, doesn't speak like one or live like a native?" (Saldivar and Walsh 2015, 65, translation ours)

Today, defining who is indigenous assumes a new challenge because of multiculturalist declarations and social policies that seek to protect indigenous rights, including the right to self-identification.

Now, for the first time, nearly all of the nineteen Latin American censuses (Cuba and the Dominican Republic are the exceptions) identify the indigenous in some way. However, they use almost as many definitions of indigeneity as there are countries in the region (Telles and PERLA 2014); these definitions respond to diverse ideas, political interests, and varied constituents (Loveman 2014), reflecting the politics of census-taking as well as the lack of consensus on the essential attributes of indigenous identity (Weaver 2001; Loveman 2014). The indicator used, the wording of the question, the response categories, and who does the classifying (that is, self or interviewer) affect indigenous population estimates (Telles and PERLA 2014) and the extent of ethno-racial inequality (Telles and Lim 1998; Bailey, Loveman, and Muniz 2013; Telles, Flores and Urrea-Giraldo 2015). Theoretically, the statistical variation in indigenous ethnicity reflects the often-porous boundary between indigenous and mestizo. A notable example is Bolivia, which was considered the only Latin American country with a majority indigenous population. That population unexpectedly dropped from $62 \%$ in 2001 to $42 \%$ in 2012 , primarily because of changes in the census wording and the response categories rather than demographic changes or changes in indigenous identity (Moreno 2014).

\section{Sources of Indigenous Classification}


With the support of an international human rights regime, indigenous peoples throughout Latin America have demanded, and often obtained, legal recognition and the expansion of basic rights. Paramount among these is the recognition that identifying the indigenous is fundamental for designing and implementing public policies that defend their social, economic and cultural rights. While indigenous language fluency had been the primary indicator for classifying the indigenous in Latin America since the nineteenth and during most of the twentieth century (Loveman 2014), selfidentification has become the new norm (del Popolo and Oyarce 2005). Mexico and Bolivia, which have collected information on indigenous language since the nineteenth century, now use both language and self-identity criteria concurrently, while Peru's Census has used only the former (Loveman 2014; Sulmont and Valdivia 2013). The two indicators are often inconsistent as increasingly fewer Latin Americans speak indigenous languages although they may identify as indigenous, or as part of a particular ethnic group (e.g. Maya, Aymara). However, the use of selfidentification may also include persons who have redefined or rediscovered an indigenous identity as a way to gain recognition or resources from the nation state or international NGOs (Canessa 2007) or that assert an indigenous (Mexica) identity in a country (Mexico) that they feel is in danger of losing its indigenous roots (Rostas 1991). Certainly, they can be considered as indigenous because of pre-conquest ties to the original people but they may previously not have identified as such and not be strongly attached to marginalized indigenous communities. Consistent with this, Villarreal (2014) finds that speakers of indigenous languages in Mexico, on the whole, tend to have stronger ties to indigenous communities and are poorer than those who self-identify as indigenous. Moreover, as indicated earlier, self-identity itself may vary widely depending on the design of census and survey questions and response categories. Harris (1970) used the term "categorical ambiguity" to note that racial ambiguity may arise depending on the ethno-racial categories used. For example, the largely white countries of Argentina and Uruguay use questions based on indigenous descent but these seem quite at odds with standard ideas of who is indigenous in 
countries like Mexico and Peru. The Brazilian census asks, "What is your color or race”, with a single "indigenous" response category (along with white, mixed, black and yellow/Asian); the Guatemalan census asks "Which ethnic group do you belong to?", with many indigenous response categories, while Ecuador simply asks how respondents "consider themselves", with three indigenous groups as response categories (Telles and PERLA 2014).The proportion of persons identifying as "indigenous" may be particularly low in countries, such as Peru, where the term may be less familiar to respondents or especially stigmatized while terms that refer to one's particular ethnic group or tribe are more familiar or acceptable (Sulmont and Callirgos 2014). De la Cadena's (2003) aptly-titled book, Indigenous Mestizos, notes that many Peruvians identify as mestizo although they speak indigenous languages, have indigenous traits, are perceived as indigenous or assume indigenous identification in particular situations.

An alternative approach is to rely on classification by others such as the interviewer. Originally, the idea of Indians or indigenous was created by Europeans based on the natives' physical features, regardless of their own identifications (Hannaford 1996; Wade 1997). "Visible difference" or phenotype was the basis of ethnic classification in earlier censuses (Forte 2013:7; see also Loveman 2014), and such classification by others occurs routinely in everyday interactions. Whether one is perceived as indigenous has arguably greater social consequences for the stigmatized, such as in being the targets of racism and discrimination, although self-identification may be more important in realms like social movements or politics. Over time, the racialization of various ethnic groups as indigenous became embedded in social and cultural practices and understandings as a natural societal classification. Racialization was often based primarily on physical attributes, although also on the language, dress and dietary habits associated with native populations (Forte 2013). Indeed, prior to the 1950s, census interviewers were often instructed to use criteria such as attire, footwear and diet, as well as appearance, for classifying persons as indigenous (Loveman 2014). 
In terms of self-identity, Wimmer (2013) notes that individuals choose ethnic identities according to self-interest and the logic of a situation, in contexts defined by a particular distribution of power, political networks and institutional order. Traditionally, the indigenous were highly stigmatized and powerless; those without any choice, such as monolingual indigenous speakers, the poorest and the most rural, tended to classify as such (de la Cadena 2003; Friedlander 2006). Upward mobility (as in "money whitens") or mobility out of a largely indigenous area could allow one to classify as non-indigenous (de la Cadena 2003; Martinez Novo 2006). However, with the growing recognition of multiculturalism, the past two decades have seen new struggles associated with indigenous identity (Hale 2006). These struggles are often associated with new indigenous leaders and political movements for indigenous rights, and have led to a resurgence of indigeneity and a transformation of collective identification (Field 1994, Nagel 1997).

In Mexico, for example, indigenous growth has been particularly great in urban areas and has far exceeded what natural demographic change could explain (Barbary and Martinez Casas 2016; Martinez Casas 2007). Although changes in the census question wording may offer a partial explanation (Martinez Casas et al. 2014), upwardly mobile individuals and migrants to cities are increasingly identifying as indigenous (Barbary and Martinez Casas 2016; Martinez Casas 2007). This trend suggests a novel source of indigenous identification that is not restricted to Latin America. There has also been a resurgence of American Indian identification in the United States, tripling since 1970 largely because higher educated persons and residents of metropolitan areas reclassified into that category (Eschbach, Supple, and Snipp 1998; Nagel 1997; Snipp 1989). Such persons could avoid the stigma of indigeneity because of social and geographic mobility but the stigma decreased while an Indian Pride emerged. Eschbach, Supple and Snipp (1998) calls these new population sectors "new Indians."

This analysis focuses on Mexico and Peru, the two countries with the largest indigenous populations in the Western Hemisphere. They share large indigenous populations and a similar 
colonial past, yet there are important differences among them. Mexico's ideology of mestizaje has been particularly dominant compared to other Spanish-speaking countries but it has also had a history of indigenous organizing, resistance and social movements (Martinez Casas et al 2014, Postero 2004). Indigenous politics gained a notable re-emergence with the Zapatista rebellion in 1994, which represented indigenous resistance to Mexico's neoliberal turn marked by the signing of the North American Free Trade Agreement (NAFTA). The weakening of corporatist and clientelistic mechanisms once controlled by the one-party system would also allow groups like the Zapatistas to assert rights based on indigenous identity, as well as on Mexican national citizenship (Stahler-Sholk 2007; Postero 2004). This change and others, including the Constitutional declaration of Mexico as "pluricultural", have ushered in an era of strengthened indigenous leadership and identity, and have presumably challenged the decades-old ideology of mestizaje. While Mexico has been more like the Latin American norm, Peru has discouraged indigenous identities and has had little in the way of indigenous social movements (Garcia 2005; Lucero 2013; Yashar 2007). Since the mid-twentieth century, the Peruvian state has institutionalized the category of "peasant" in lieu of "Indian," reflecting an ideological orientation that favors class over race. The state has referred to a "peasant problem" requiring land reform and economic development, rather than an Indian problem, as in other Latin American countries. Except for linguistic markers such as maternal language, the Peruvian census has not used any other indicator of ethnicity since 1940.

\section{Data and Analytical Strategy}

We use novel survey data for Mexico and Peru that include multiple measures of indigeneity. The data were collected in 2010 by the Project on Ethnicity and Race in Latin America (PERLA) by survey firms in Mexico and Peru. ${ }^{1}$ PERLA is the only survey currently existing in Latin America that is specifically designed to examine indigenous classification by varying the questions, 
categories and methods of capture. The Peruvian sample consists of 1,500 nationally representative random household surveys of adults age 18 and older. In Mexico, the sample is a nationally representative random household survey of 1,000 adults and an oversample of 500 indigenous Mexicans. These surveys employed a four-stage sampling design that selected random municipalities in each country, blocks, households, and individuals within households on the basis of apportionments for age and sex to produce a self-weighting sample. All surveys were interviewer-administered by co-nationals in respondents' homes. There was no systematic pairing on ethnicity though indigenous students accompanied interviewers to indigenous areas (of the same language) where they provided translation services when needed.

The indigenous oversample in Mexico used the same four-stage sampling design to select persons that self-identified as indigenous in a sample of regionally diverse municipalities with a large number of indigenous language speakers. The analysis for Mexico use only the nationally representative sample in Table 1 while all of the remaining analyses in the Mexican case use the entire sample including the indigenous oversample, and use post-stratification weights to yield the total sample representative of the Mexican population.

Analytical Plan: The analysis includes four components. First, we offer a descriptive analysis of the proportion of Mexicans and Peruvians classified as indigenous using twelve indicators included in the surveys. The twelve components are listed on Table 1 and include several versions of self-identification, language knowledge, ancestry, and interviewer's identification. All but "D" (indigenous classification by the interviewer) are self-reported. The data include criteria available in the survey but unfortunately exclude criteria such as living in an indigenous community.

The second component empirically uncovers different types of ethnic identity using the indicators included in the survey using latent class analysis (LCA). LCA is a multivariate technique 
that extracts latent constructs from a set of categorical indicators. The technique assumes a model in which the indicators are uncorrelated with each other, given the scores on the latent variable (that is, conditional independence between indicators after accounting for class membership). After controlling for latent classes, only random association between the variables is assumed to remain (McCutcheon 1987; Vermunt and Magidson 2000). We use standard fit statistics including the likelihood ratio, the Bayesian Information Criterion (BIC) and the Akaike Information Criterion (AIC) to determine the number of latent classes that best account for patterns of variation in the data, and interpret the groups that emerge from the analysis as different types of ethnic identity.

The third component of the analysis examines the demographic and socio-economic factors shaping these types of ethnic identity. We treat the ethnic types emerging from the latent class analysis as our dependent variables and implement a multinomial logit model (MNL) predicting the respondents' ethnic type based on their sociodemographic characteristics. A multinomial logit model examines the association between a set of predictors and each category of a polytomous dependent variable, using one category as baseline for comparison.

The following predictors are included in the model: Respondent's age measured in years, education measured in years of completed schooling, sex, urban residence, skin color, and household socioeconomic status. Skin color was rated by the (co-national) interviewer before the survey began, using a 11-category color palette ranging from very light (1) to very dark (11). The palette was extensively pre-tested for interviewers' ease of use and representativeness of skin colors found in Latin America (Telles and PERLA 2014). Household socioeconomic status is a composite index based on ownership of a set of household assets and consumer durables, including piped water, inside toilet, stove, TV, refrigerator, telephone, washing machine, car, computer, flat screen TV and internet. These items were combined using principal component analysis; the first component (the linear combination that accounts for the largest portion of common variance) was 
used as the index of socioeconomic status (Torche and Spilerman 2009). The index has a standard deviation of 1 by construction.

The last component of the analysis studies the association between ethnic types and attitudinal variables to examine the ideological corollaries of different modes of ethnic identification. We examine six attitudinal variables about ethnic mixing, collective organization, conflict and discrimination. The attitudinal questions are the following:

1. "Intermixing of people with different origins/races is good for the country" Agree, neither agree nor disagree, disagree. (Mestizaje).

2. "I agree with indigenous political organizations that seek to reclaim indigenous rights" Not at all or a little, some, a lot. (Indigenous Organization)

3. "In this country, are indigenous people treated better, the same, or worse than whites?" Not at all or a little, some, a lot. (Systemic Discrimination)

4. "In this country, there is a lot, some, a little, or no conflict between indigenous and whites" Not at all, a little, some, a lot. (Perceive Ethnic Conflict)

5. "I have witnessed discrimination against indigenous language speakers" Not at all, rarely, sometimes, often. (Witnessed Discrimination)

6. "I have felt discriminated against because of my accent or the way I speak" Not at all, rarely, sometimes, often. (Personal Discrimination)

We conducted separate analyses for Mexico and Peru. For each country, we predicted each attitudinal variable based on ethnic type, and we account for the same sociodemographic controls as in the prior analysis. We used ordered logit models because all the dependent variables have three or more ordered categories but no interval-ranking of these categories can be assumed.

Several of our variables have a small number of missing observations. We implemented two strategies to address the issue of missing data. The first strategy list-wise deleted cases with 
missing observations in any of the variables. The second one implemented multiple imputation using a chained equations routine with 20 imputations (Allison 2002). Results from the two strategies are virtually identical so only the analyses with list-wise deletion are presented.

\section{Descriptive Analysis}

Table 1 shows the percentages of the Mexican and Peruvian respondents that are classified as indigenous using twelve criteria. Depending on the measure used, we find that the indigenous population in Mexico varies from 8.8\% of the national population using interviewer classification (item D in Table 1) to $27.6 \%$ using grandparent's language (item L). The variation is substantially greater in Peru. Only 4.7\% of the population self-identify as indigenous when asked to identify among a set of five mutually exclusive categories that arguably reflect a racial taxonomy (indigenous, white, black, mulato, and mestizo) (item B). Fully $49.8 \%$ self-identify as indigenous when using grandparent's language (item L), a ratio of more than 10:1. In Mexico, $12.4 \%$ of the population self-identify as "indigenous" when using the five mutually-exclusive options, suggesting that indigenous is a more acceptable term than in Peru.

From another perspective, about twice as many Mexicans identify in an indigenous ethnic group based on their ancestry and customs (22.2\%) compared to the percentage when the five (racial) categories are offered (12.4\%). This compares to a ratio of 5:1 in Peru: $23.5 \%$ based on ancestry and customs, and only $4.7 \%$ based on the five mutually-exclusive categories. These results show a particularly strong reluctance to self-identify as "indigenous" in Peru, even though a larger proportion of the population acknowledges origins in an indigenous ethnic group based on ancestry and customs. This finding is consistent with de la Cadena's (2003) report of indigenous language speakers who do not identify as indigenous in Peru due to lack of familiarity with the term or to its stigmatization and with Yashar's (2005) comparative analysis showing Peruvian exceptionalism as an "indigenous country without indigenous people". 
The last row of Table 1 shows estimates based on grandparent's language (item L), which yields an especially large indigenous population for Peru (49.8\%) compared to Mexico (27.6\%). While such a measurement may seem uncommon, it is not outside the realm of possible sources of identification considering that the recent Uruguayan and Argentine censuses classify the indigenous on whether respondents have any indigenous ancestry (Telles and PERLA 2014). Our examination of the indigenous language items reveals that fully $42.5 \%$ of Peruvians understand an indigenous language at least partially (F) and 23.4\% are fluent indigenous language speakers (item C). This compares to considerably lower numbers of $20.9 \%$ and $16.2 \%$ in Mexico, respectively. The language figures also reveal a more rapid language loss across generations in Peru compared to Mexico when comparing grandparents', parents' and respondents' knowledge of an indigenous language (items L, K, and C).

An interesting comparison is between self- and interviewer- indigenous classification (items B and D in Table 1). More persons identify as indigenous (12.4\%) than are perceived as indigenous in Mexico (8.8 percent, difference significant at the $\mathrm{p}<.001$ level), while the opposite is true in Peru (4.7\% and 6.3\% respectively, difference significant at the $\mathrm{p}<.008$ level). Although selfidentification has become standard practice in surveys around the world, classification by others provides a more direct measure of how people are perceived by others (Clearly, interviewerclassification reflects only one particular viewpoint of another's classification). Both self- and otherclassifications for indigeneity are low in Mexico and Peru-much lower than identification with a particular indigenous group on the basis of traditions and customs. Furthermore, the correlation between these two measures is far from perfect-Pearson's $r$ is .47 in Mexico and .41 in Peruleaving substantial room for the diverse sources of identification that we explore in the next section.

\section{Uncovering Ethnic Types.}


We used latent class analysis (LCA) to empirically uncover different types of ethnic identity using the indicators of indigeneity included in the survey. Some of the indicators presented in Table 1 are highly correlated with each other, making it difficult to implement LCA with a limited number of cases. To reduce redundancy, we combined highly correlated indicators. Mother's and father's indigenous language (I and J) display high bivariate correlations (Pearson's $r$ is .88 in Mexico and .78 in Peru). We combined these indicators with a variable capturing whether both parents speak an indigenous language $(\mathrm{K})$. We also consolidated the ethno-racial classification of parents, based on the respondent's report, into a single indicator coded 1 if both parents were indigenous ( $G$ and $\mathrm{H})$. We dropped speaking fluency in an indigenous language (C), while retaining understanding of an indigenous language (F) (Pearson's $r$ for these items is .88 in Mexico and .64 in Peru). Finally, we eliminated grandparents' ability to speak an indigenous language from further analyses, since this measure provides tenuous measure of indigeneity if the focus is on how individuals identify themselves. This yields a total of seven dichotomous indicators.

Using LCA, we examined the response patterns to the seven dichotomous items to determine the number of latent classes - characterizing different ethnic types-necessary to account for the association between observed variables. This strategy allows us to empirically obtain the number of ethnic types that best accounts for the data in each country, instead of arbitrarily imposing a certain number of groups. We evaluated solutions with different numbers of latent classes using three fit statistics: the likelihood-ratio test (LR), the Bayesian Information Criterion (BIC) and the Akaike Information Criterion (AIC). Once a solution with an acceptable number of classes based on fit statistics is found, then respondents are assigned to the latent class for which they have the highest posterior membership probability. We conducted the analysis separately for Mexico and Peru.

Table 2 about here 
Results of LCA for 1 to 5 classes in Mexico and Peru are reported in Table 2. Solutions identifying 1, 2, and 3 classes had a poor fit in both countries. The 4-class model fits the data best under the BIC but does not fit well using the conventional LR test $(\mathrm{p}<.05)$. The LR test led us to prefer a 5-class model in Peru and a 6-class model (not shown) in Mexico. A limitation of the LR test is that it favors negligible improvements in the fit even at the cost of additional parameters if the sample size is relatively large. In contrast, the BIC coefficient takes into account gains in terms of fit and losses in terms of parsimony for a given sample size. As a result, we relied on the BIC statistic for selecting models with 4 latent classes in both countries. Table 3 presents the profiles of these latent classes and their relative sizes.

Table 3 about here

The first latent class is comprised of individuals with a high probability of understanding an indigenous language, of having parents who speak/spoke an indigenous language and, in the case of Mexico but not Peru, of having an indigenous first language. According to Table 3, in Mexico (/Peru) 99 (/90) percent of the members of this group understand an indigenous language, 80 (/82) percent of them have parents who speak an indigenous language, and $73(/ 10)$ percent of them have an indigenous first language. In contrast, this group has a low probability of identifying as indigenous when five ethnic categories (indigenous, mestizo, white, mulato, black and other) are offered —only 12\% in Mexico, virtually zero in Peru—or even of identifying their parents as indigenous. Fully $70.8 \%$ of this group self-identify as mestizo in Mexico as do $88.3 \%$ in Peru (not shown). Furthermore, Table 3 indicates that a relatively small proportion of this group (23\% in Mexico, 5\% in Peru) were identified as indigenous by interviewers. On the basis of these patterns, we describe this group as Indigenous Mestizos. They tend to acknowledge a language-based ethnic 
origin but are not likely to choose "indigenous" as their main ethnic identity. Even though the probability that this group uses other markers of indigenous belonging is higher in Mexico than Peru, their central source of indigenous identity in both cases is their linguistic background or understanding.

In many ways, the second latent class captures the opposite of Indigenous Mestizos. While its members have much lower probabilities of understanding an indigenous language, they are more likely to identify as indigenous using the five-category question, and to report being part of an indigenous ethnic group based on ancestors and customs, particularly in the case of Peru. They are also more likely to report indigenous ancestry based on parents' indigeneity, even if they report that their parents did not speak an indigenous language. These attributes lead us to identify this group as New Indians - people who value and assert an indigenous background and traditions, even if they cannot speak an indigenous language.

Table 3 shows that, based on the latent class model, in Mexico, 57\% of New Indians indicate that they belong to an indigenous ethnic group based on their ancestors and customs, $43 \%$ choose "indigenous" as their ethno-racial identity using the five mutually exclusive categories, and 56\% report having indigenous parents. However, only $29 \%$ understand an indigenous language and just $6 \%$ report an indigenous language as their first language. In Peru, fully $97 \%$ of New Indians indicate that they have origins in an indigenous ethnic group according to ancestors and custom and $71 \%$ of them report an indigenous background based on parents' indigeneity but only $45 \%$ of this group understands an indigenous language and 3\% report an indigenous first language. New Indians' ethnic identity is reminiscent of an "invented tradition" (Hobsbawm 1983): in spite of having lostor never having had-knowledge of an indigenous language, they explicitly proclaim an indigenous identity.

While Indigenous Mestizos and New Indians articulate novel sources of indigeneity in Latin America, the remaining two ethnic types align more closely with traditional understandings of 
indigeneity (or lack thereof). In both Mexico and Peru, members of the third latent class in Table 3 are very likely to identify as indigenous using all sources of identification, including language, belonging to an indigenous ethnic group, racial self-identification and interviewer identification. Hence, we call them Traditional Indians. The only discernable difference between the two countries is that in Peru, even this group has a relatively low probability of selecting "indigenous" as their primary racial identity (26\% of the group does so) and of being seen as indigenous by interviewers (30\%). In Mexico, by contrast, 85\% of this group's members identify as indigenous, and 66\% are seen as indigenous by the interviewer. This again speaks to the lack of familiarity and stigmatization of the term indigenous in Peru. Finally, members of the fourth latent class display consistently low probabilities — close to zero in most cases-of identifying as indigenous based on any of the selected indicators. We then call them Non-Indigenous. In spite of the historical differences between Mexico and Peru, these four groups are fairly similar across countries.

\section{Socio-demographic Correlates of Ethnic Types}

Having distinguished four ethnic types, the question arises about the demographic and socioeconomic factors that distinguish these groups. We expect that, as in the United States, new Indians are likely to be more educated and urban, representing a sector of non-traditional individuals whose ethnicity is more symbolic and awakened by an ethnic revival (Eschbach, Supple, and Snipp 1998; Nagel 1997; Snipp 1989). To address this question, we implemented a multinomial logit model treating ethnic types as the dependent variable. We used the Non-Indigenous group as the reference category and compared the factors correlated with identifying as Traditional Indians, New Indian, and Indigenous Mestizos vis-à-vis the Non-Indigenous. As indicated, the following predictors are included in the model: Respondent's age, years of schooling, sex, urban residence, skin color, and household socioeconomic status. 
Before presenting the results, it is important to highlight that the association between each predictor and ethnic type captured by the parameter estimates cannot be given a causal interpretation. Predictors were measured contemporaneously with the outcome and they do not vary exogenously; they are therefore vulnerable to endogeneity in the form of reverse causality or spuriousness. The objective of the multivariate analysis is to provide a descriptive profile of different ethnic types rather than to establish causal effects. The valid interpretation of this model is based on the independence of irrelevant alternatives (IIA) assumption, which states that the odds for each specific pair of outcomes do not depend on the availability of other outcomes. The SmallHsiao test (Small and Hsiao 1985) suggests that IIA assumption is met with chi-square p-values larger than .05 for all categories of the dependent variable in both countries.

Table 4 about here

Table 4 reports the results of the multinomial logit analysis. Compared to the NonIndigenous group, Traditional Indians are less educated, darker, and much poorer (for predicted probabilities of belonging to each indigenous type see the Online Appendix). For example, holding other variables constant an additional year of schooling is associated with an 8.2 percent decrease $\left(\mathrm{e}^{-.086}=.918,1-.918=.082\right)$ in the chances of being a traditional Indian compared with nonindigenous, one additional darker tone in the 11-category color palette is associated with an increase of 42.8 percent $\left(\mathrm{e}^{0.356}=1.428\right)$ in the odds of being a traditional Indian, and a 1 -standard deviation increase in the household SES scale is associated with a .677 decline $\left(\mathrm{e}^{-1.13}=.323,1-.323=.677\right]$ in the odds of being a traditional Indian compared with being nonindigenous. In Peru, a 1-unit increase in schooling, skin color, and household SES is associated, respectively with a 5.9 percent decrease $\left(\mathrm{e}^{-061}=.941\right), 21.5$ percent increase $\left(\mathrm{e}^{.195}=1.215\right)$, and 47.8 percent decrease $\left(\mathrm{e}^{-.475}=.622\right)$ in the chances of being a traditional Indian compared to identifying 
as Non-Indigenous. ${ }^{2}$ These socio-demographic differences show similar patterns in Mexico and Peru and they fit the conventional understanding of the indigenous populations as underpriveleged, even if, interestingly, Traditional Indians are not more likely to live in rural areas than nonindigenous people, a likely corollary of massive urban migration.

Beyond these expected differences, the socio-demographic characteristics of Indigenous Mestizos and New Indians help in understanding these novel types of Latin American indigeneity. Indigenous Mestizos emerge as an intermediate category between the Non-Indigenous and Traditional Indians in both socioeconomic standing and skin color. Comparison of the parameter estimates associated with skin color and household SES indicates that indigenous mestizos tend to be darker and more disadvantaged in terms education and assets than Non-Indigenous, but not as disadvantaged as Traditional Indians. Remember that Indigenous Mestizos' indigeneity is defined by their understanding of an indigenous language combined with their choice to primarily identify as mestizo rather than indigenous.

Probably the most remarkable ethnic type is the New Indians. In both countries, New Indians are a younger group, and much more highly educated than both Traditional Indians and Indigenous Mestizos; in fact, their levels of schooling resemble the Non-Indigenous. As shown in Table 4, in both Peru and Mexico there is no difference in the level of schooling and skin color between new Indians and non-indigenous people at the conventional p<.05 level. Strikingly, New Indians are more likely to be urban than Non-Indigenous people in both countries (the difference is statistically significant only in Peru). What emerges from this characterization is a group comprising young, educated, and relatively light-skinned urbanites who, although they have not (ever) mastered an indigenous language, appear willing to affirm their indigenous ancestry and identity. In fact, in a separate analysis (table not shown) we found that fully $35.2 \%$ of New Indians in Mexico and 36.0\% in Peru did not have a single grandparent that spoke an indigenous language, suggesting that an indigenous identity is based on individual choice rather than ancestry for some 
members of this group. Although New Indians are a small group in both countries, they may be a harbinger of ethnic identification in a context of educational expansion, urbanization and renewed recognition of minority groups.

\section{Attitudinal Differences across Ethnic Types}

We have characterized four indigenous types by examining their distinct sources of indigenous identification and their socio-demographic characteristics. One important reason why these distinctions matter is because they may shape different attitudes and political orientations. Do these distinctions among the indigenous identity types make a difference in terms of political behaviors or opinions or do the distinctions reflect socio-demographic differences without attitudinal corollaries? We hypothesize that New Indians are more political since they are more likely to choose to identify in the stigmatized indigenous category. In order to explore this, we examine whether these ethnic types vary on attitudinal variables that measure level of agreement with six questions capturing the respondents' opinions about the desirability of ethnic mixing (mestizaje), support of indigenous political organizations (indigenous organizations), perception of societal discrimination of indigenous people (systemic discrimination), perception of ethnic conflict (ethnic conflict), whether the respondent has witnessed discrimination against indigenous people

(perceived discrimination), and whether they had experienced discrimination themselves (personal discrimination).

Ordered logit models for each attitudinal outcome were separately estimated for Mexico and Peru, accounting for the same sociodemographic covariates as those included in Table 4. Indigenous type is operationalized as a set of dummies and Non-Indigenous is excluded and used as the baseline for comparison. Naturally, calculating the parameter estimates for any ethnic group pairwise comparison is trivial. 
Table 5 about here

In both countries, the most significant attitudinal gap is between Non-Indigenous and all types of indigenous groups (Table 5). However, interesting differences among indigenous types emerge. In Mexico, all indigenous groups are more likely to support political organizations for reclaiming indigenous rights than non-indigenous, with no significant differences (at the $\mathrm{p}<.05$ level) between them. However, New Indians are significantly more likely than non-indigenous and other indigenous groups to believe that there is conflict between whites and indigenous people and to maintain that indigenous people are treated worse than non-indigenous (systemic discrimination), net of all the socioeconomic factors.

Interestingly, Mexican New Indians appear to be have a heightened sense of ethnic disparities and conflict compared with Traditional Indians, which is arguably the group that has experienced the most discrimination. New Indians are also the most likely group to identify mistreatment of indigenous people compared to whites, even if they are not more likely than other indigenous groups to have witnessed or directly experienced discrimination. In fact, both traditional Indians and indigenous mestizos are significantly more likely to have witnessed discriminations against people who speak an indigenous language than New Indians. Moreover, Mexican New Indians are the least likely of the groups to believe that intermixing of people with different origins/races is good for the country. This group is thus most likely to challenge the dominant national ideology of mestizaje, although differences are statistically significant only with Indigenous Mestizos ( $b=-.722$, se=.327 p=.027). Together, these findings suggest that Mexican New Indians' ethnic identity is particularly political and that they are especially likely to challenge the conventional discourse that Mexican society is non-discriminatory, has little ethnic conflict, and embraces mestizaje, even if they do not report having personally suffered from anti-indigenous prejudice. 
While Mexican New Indians are particularly political, New Indians in Peru appear to be less distinct ideologically from other indigenous groups. Still, they are more likely to reject racial intermixing as good for the country, along with Traditional Indians and in sharp contrast with Peruvian indigenous mestizos, who are more likely to support ethnic intermixing. All of Peru's indigenous groups report witnessing more discrimination than Non-Indigenous but only Indigenous Mestizos and Traditional Indians report a higher likelihood of experiencing discrimination themselves. As in Mexico, Peruvian New Indians do not appear to experience more discrimination than Non-Indigenous.

In Peru, there are no significant differences between Non-Indigenous and any of the indigenous ethnic types in terms of perceiving ethnic conflict or systemic discrimination against indigenous people. By examining all of the pairwise comparisons between ethnic groups, a single significant contrast emerges: Indigenous Mestizos are less likely to perceive ethnic conflict than Traditional Indians (difference in parameter estimates $(.242--.181=.423, \mathrm{p}=.025)$ ). Added to Indigenous Mestizos' approval of ethnic intermixing, this group again emerges as the least inclined to emphasize ethnic cleavages that challenge the status quo. In general, attitudinal differences among ethnic groups appear to be weak in Peru, aligning with the literature of weak indigenous identities in Peru (Yashar 2005).

\section{Discussion and Conclusion}

Scholars have long known that ethno-racial classification is fluid in Latin America, but have lacked the data and analytical tools to examine sources and patterns of variation systematically. Specifically, social scientists, census bureaus, and others have struggled with deciding how to classify the indigenous; holding widely different conceptions based on phenotype, language, ancestry and self-identification, they have found little agreement (Del Popolo and Oyarce 2005, 
Loveman 2014, Rosemblatt 2018). We have sought to develop a more comprehensive understanding of who is indigenous and of the diverse modes for being indigenous in Latin America.

Relying on a new dataset with multiple measures of indigeneity, we have shown that the size of the indigenous population varies widely according to the marker of indigeneity chosen. Across twelve plausible indicators for indigenous classification, we have found that estimates of the indigenous population vary from $9 \%$ to $28 \%$ in Mexico and fully $5 \%$ to $50 \%$ in Peru. This suggests that variations in the measured size of the indigenous population across countries and over time are deeply dependent on measurement options. The main source of difference between Mexico and Peru is that many Peruvians report fluency in an indigenous language and accept identity in an indigenous group or but do not consider themselves "indigenous" and interviewers are hesitant to use that term when identifying respondents.

We provide, for the first time, an empirically-obtained profile of indigenous types in Latin America. Using multiple measures of indigeneity and latent class analysis to uncover meaningful indigenous groups, we find that contemporary indigenous classification clusters around four types: persons who are almost invariably indigenous across all measures, who we call Traditional Indians; persons who do not speak or understand indigenous languages but who assert an indigenous identity - we call them New Indians; persons who speak an indigenous language but often are reticent to identify as indigenous - we call them Indigenous Mestizos; and a group of mostly Spanish monolinguals with hardly any indigenous markers, who we call the Non-Indigenous population. Traditional Indians are indisputably indigenous by almost any indicator, including selfidentification as indigenous, speaking an indigenous language, having indigenous parents, and identification as indigenous by an interviewer. Indeed, Traditional Indians are the primary subject of anthropological research as well as the stereotypical Indian in popular convention. Compared to 
the other indigenous types, their identities are thickest, the most consequential and the least symbolic.

Indigenous Mestizos are situated between Traditional Indians and the non-Indigenous. Although both Indigenous Mestizos and Traditional Indians are similarly dark-skinned and speak an indigenous language, the former group often identifies as mestizo, is more socioeconomically advantaged and (in the case of Mexico) urban, making them more like the culturally and socially assimilated mestizos and socially distant from Traditional Indians. Such an identity may thus emerge as a relational ethnicity, likely constructed by the Indigenous Mestizos as a way of distinguishing themselves in a higher status group from the poor Indians they left behind. Indigenous Mestizo is a particularly widespread type in Peru, likely reflecting the greater stigma of indigeneity and perhaps related to the Peruvian category of cholo, which is intermediate to indigenous and mestizo (Bourricaud 1975, Sulmont and Valdivia 2013).

Given the decline of indigenous language use in both Mexico and Peru in recent decades, we would expect a decline in the indigenous populations using the traditional language indicator. However, new ethnic types appear be emerging, in particular a group that we have called New Indians. In spite of not knowing or understanding an indigenous language, New Indians are likely to assert an indigenous identity. People in this group are substantially younger, more prosperous, and more urban than the other two ethnic types. Interestingly, more than one-third of New Indians do not have a single grandparent who spoke an indigenous language, and the average skin color of New Indians is similar to the non-indigenous, which suggests a relatively tenuous claim to indigeneity. These findings suggest that New Indians embrace an indigenous identity even if they would not normally be perceived as indigenous by others, and even if there is no indication of traditional indigenous markers for themselves or for their parents. This novel indigenous identity is likely to have emerged in the context of growing multiculturalism and indigenous movements. 
Although about the same proportion of the national population $(7-8 \%)$ is considered New Indian in both countries, New Indians comprise more than a third of Mexican indigenous and less than one-fifth of the Peruvian indigenous population. New Indians may be emerging as a formidable political subject, particularly in Mexico where they challenge the traditional notions that mestizaje is good for the country and that ethnic relations in the country are non-discriminatory and nonconflictual. This suggests an especially ideologically committed group that holds indigenous rights as an important value, even though they are not directly affected by discrimination and prejudice and have relatively weak ties to Indigenous ancestry..

The complexity of indigenous identity that we find speaks to ethnic boundaries, assimilation and mestizaje. While the non-indigenous and traditional Indians are clearly positioned on either side of a dichotomous boundary that represents the primary ethnic boundary (between mestizos/non-indigenous and indigenous) in Latin America, Indigenous Mestizos and New Indians straddle the boundary. Both are transitioning from one side of the boundary to the other but in opposite directions, and both depart in different ways from the notion of an unproblematic "mixed race" national identity. Indigenous mestizos could be considered as assimilating, consciously or not, to a non-indigenous group by explicitly rejecting the markers of indigeneity over which they have control. Although they still speak an indigenous language, they tend to reject an indigenous identification, choosing mestizo instead. By contrast, new Indians represent an ethnic reemergence, re-positioning from the non-indigenous or mestizo side of the boundary to the indigenous side. The ethnic identity of the New Indians thus represents a new way of bridging the mestizo-indigenous boundary, which reveals a counterflow on a two-way street rather than the unidirectional flow in the direction of mestizaje, assimilation, or modernization.

Why would persons, who can identify as mestizo and are likely to be seen by others as mestizo, choose to identify counter-hegemonically as indigenous, from the mainstream to a low status group? For some, this repositioning may be symbolic as it may offer them a sense of social 
rootedness within an ethnic community without having to bear the hardships and stigma borne by Traditional Indians. But it is likely much more than the symbolic ethnicity exhibited by later generation descendants of European immigrants to the United States (Gans 1979, Waters 1990). Their political orientations suggest that their ethnicity, whether re-emergent or invented, is not merely symbolic. With multiculturalism, the stigma associated with indigeneity has lowered the cost of identifying as indigenous as has occurred in the United States (Nagel 1997, Eschbach, Supple, and Snipp 1998). Moreover, in the Mexican context New Indians may seek to invert the status hierarchy that devalues indigeneity, which is consistent with the thrust of Mexico's current multiculturalism (Martinez Casas et al 2014). A similar argument could be made for Peru albeit to a lesser extent (Sulmont and Callirgos 2014), which might help explain why New Indians are less prominent in that country.

The State defines the indigenous through their censuses, which become templates for understanding indigeneity. While census definitions rely on one or two indicators, we have sought to provide a more nuanced and sociologically informed way to understand three widely distinct types of indigeneity, which should be informative when deciding how to measure the indigenous population. By including all types as indigenous, nation-states run the risk of ignoring the perspectives of the most marginalized and those to whom indigeneity is most consequential (Canessa 2007). Our approach also suggests that the use of self-identification as the primordial method of classification (Del Popolo and Oyarce 2005) could unintentionally capture many individuals that might not be considered in the design of policies aimed at indigenous people, such as New Indians, and exclude others intended to be targets, such as Indigenous Mestizos. Moreover, prior consultation laws require indigenous people to be consulted and to consent to development/extractive projects that affect them, so which groups or collectivities are defined as indigenous may have major political and economic consequences (Sulmont and Valdivia 2012). Aside from merely capturing the indigenous population (Loveman 2014, Telles and PERLA 2014), 
our results highlight the need to carefully consider the implications of question and response category design in identifying indigenous populations, such as for measuring poverty and ethnic inequality. On the other hand, with multiple ethnic classification measuresm as used by the PERLA survey, one could provide more complex instruments for understanding poverty.

Beyond the specific characteristics of indigenous types in contemporary Latin America, our analysis has two broader corollaries. First, because there are different ways of experiencing ethnicity, it would make sense for researchers to use multiple empirical indicators to capture diverse identities rather than trying to find a single accurate indicator of the "true" ethnic marker. Second, modes of ethnicity are correlated with demographic and socioeconomic attributes that place individuals in their social context, and they give rise to attitudinal differences that express the implications of ethnic identification for social and political action. We hope these simple, but frequently neglected, corollaries result in a more discerning, informative, and accurate understanding of ethnic identity around the world. 
About the Authors:

Edward Telles is Distinguished Professor of Sociology at the University of California, Santa Barbara.

His research is on race, ethnicity, immigration and immigrant incorporation. He recently led an international and multidisciplinary team called the Project on Ethnicity and Race in Latin America (PERLA) to collect and analyze national surveys in several countries of Latin America.

Florencia Torche is a Professor of Sociology at Stanford University. Her research examines how inequality is perpetuated across generations and over the life course. She has studied intergenerational mobility, assortative mating, educational stratification, and the effect of prenatal exposures on individual health, development, and wellbeing. 


\section{References}

Abrams, Daniel M., and Steven H. Strogatz. 2003. "Linguistics: Modelling the dynamics of language death." Nature 424.6951: 900-900.

Allison, Paul. 2012. Missing data. Thousand Oaks, CA: Sage.

Bailey, Stanley R., Mara Loveman, and Jeronimo O. Muniz. 2013. "Measures of "race" and the analysis and implications of racial inequality in Brazil." Social Science Research 42.1: 106119.

Barbary, Olivier and Regina Martinez Casas. 2016. L'explosion de L'autodéclaration Indigene entre les Recensements Mexicains de 2000 et 2010. Autrepart 74-75: 215-240

Barth, Frederik. 1969. "Introduction" in Ethnic Groups and Boundaries: The Social Organization of Cultural Difference. Allen and Unwin.

Belote, Linda Smith, and Jim Belote. 1984. "Drain from the bottom: Individual ethnic identity change in Southern Ecuador." Social Forces 63.1: 24-50.

Bonfil Batalla, Guillermo. 1996. México Profundo: Reclaiming a Civilization. University of Texas Press.

Bourricaud, Francois. 1975. "Indian, mestizo and cholo as symbols in the Peruvian system of stratification." Ethnicity: Theory and Experience: 350-90.

Canessa, Andrew. 2007. "Who is indigenous? Self-identification, indigeneity, and claims to justice in contemporary Bolivia." Urban Anthropology and Studies of Cultural Systems and World Economic Development: 195-237

De la Cadena, Marisol. 2003. Indigenous Mestizos: The Politics of Race and Culture in Cuzco Peru, 1919-1991.

Del Popolo, Fabiana, and Ana María Oyarce. 2005."América Latina, población indígena: perfil sociodemográfico en el marco de la Conferencia Internacional sobre la Población y el Desarrollo y de las metas del Milenio." Notas de Población 31.79: 13-52.

Deloria, Vine. 1969. Custer Died for Your Sins: An Indian Manifesto. London: Collier-MacMillan Ltd.

Eschbach, Karl, Khalil Supple, and C. Matthew Snipp. 1998. "Changes in racial identification and the educational attainment of American Indians, 1970-1990." Demography 35.1: 35-43.

Field, Les W. 1994. "Who are the Indians? Reconceptualizing indigenous identity, resistance, and the role of social science in Latin America." Latin American Research Review: 237-248.

Forte, Maximilian. 2013. "Introduction: Who Is an Indian: The Cultural Politics of a Bad Question" in Maximilian Forte (ed.) Who is an Indian? Race, Place, and the Politics of Indigeneity in the Americas. University of Toronto Press.

Friedlander, Judith. 2006. Being Indian in Hueyapan. Macmillan.

Gans, Herbert. 1979. "Symbolic ethnicity: the future of ethnic groups and cultures in America' Ethnic and Racial Studies 2(1): 1-20.

García, M. E. 2005. Making indigenous citizens: identities, education, and multicultural development in Peru. Stanford University Press.

Hale, Charles R. 2006. Mas Que Un Indio (More Than an Indian): Racial Ambivalence and The Paradox of Neoliberal Multiculturalism in Guatemala. School of American Research Press. 
Hannaford, Ivan. 1996. Race: The History of an Idea in the West. Woodrow Wilson Center Press.

Harris, Marvin. 1970. "Referential Ambiguity in the Calculus of Brazilian Racial Identity", Southwestern Journal of Anthropology 26: 1-14.

Hobsbawm, Eric. 1983. "Introduction: Inventing Traditions." In The Invention of Tradition, edited by Hobsbawm, Eric and Terence Ranger. Cambridge: Cambridge University Press.

Hoetker, Glenn. 2004. "Confounded Coefficients: Extending Recent Advances in the Accurate Comparison of Logit and Probit Coefficients Across Groups.” Working Paper, October 22, 2004. Retrieved 11/12/2017 from https://papers.ssrn.com/sol3/papers.cfm?abstract id=609104

Jung, Courtney. 2003."The politics of indigenous identity: Neoliberalism, cultural rights, and the Mexican Zapatistas." Social Research: An International Quarterly 70.2 : 433-461.

Loveman, Mara. 2014. National Colors: Racial Classification and the State in Latin America. Oxford.

Loveman, Mara, and Muniz, Jeronimo. 2007. "How Puerto Rico became White: Boundary Dynamics and Intercensus Racial Reclassification." American Sociological Review, 72.6: 915-939.

Lucero, Jose Antonio. 2013. “Encountering Indigeneity: The International Funding of Indigeneity in Peru" Chapter 7 in Maximilian Forte, Who is an Indian? Race, Place, and the Politics of Indigeneity in the Americas. University of Toronto Press.

Mallon, Florencia E. 1992. "Indian communities, political cultures, and the state in Latin America, 1780-1990." Journal of Latin American Studies 24.S1: 35-53.

Martinez Casas, Regina. 2007. Vivir Invisibles: la Resignificación Cultural entre los Otomíes Urbanos de Guadalajara. CIESAS.

Martinez Casas, Regina, Emiko Saldivar, Rene D. Flores and Christina A. Sue. 2014. "The Different Faces of Mestizaje: Ethnicity and Race in Mexico." Pp. 36-80 in Pigmentocracies: Ethnicity, Race and Color in Latin America by Edward Telles and Project on Race and Ethnicity Chapel Hill: University of North Carolina Press.

Martinez Novo, Carmen. 2006. Who Defines Indigenous? Identities, Development, Intellectuals and the State in Northern Mexico. New Brunswick: Rutgers University Press.

McCutcheon, Allan. 1987. Latent Class Analysis. Sage, Newbury Park, London.

Moreno, Daniel E. 2014. “The Indigenous Population in the Bolivian Census” Annual meetings of the Latin American Studies Association. San Juan, Puerto Rico.

Nagel, Joane. 1997. American Indian ethnic renewal: Red power and the resurgence of identity and culture. Oxford University Press.

Postero, Nancy Grey. 2004. The Struggle for Indigenous Rights in Latin America. Sussex Academic Press.

Rosemblatt, Karin Alejandra. 2018. The Science and Politics of Race in Mexico and the United States. Chapel Hill: University of North Carolina Press.

Rostas, Susanna. 1991. "The Concheros of Mexico: A Search for Ethnic Identity." Dance Research 9 (2): 3-17.

Saldivar, Emiko and Walsh, Casey. 2015. "Racial and Ethnic Identities in Mexican Statistics” Journal of Iberian and Latin American Research 20(3): 455-475. 
Small, Kenneth and Cheng Hsiao. 1985. "Multinomial Logit Specification Tests." International Economic Review 26:619-627.

Snipp, C. Matthew. 1989. American Indians: The first of this land. Russell Sage Foundation.

Stahler-Sholk, Richard. 2007. "Resisting Neoliberal Homogenization: The Zapatista Autonomy Movement." Latin American Perspectives, 34(2): 48-63.

Sue, Christina, and Tanya Golash-Boza. "Blackness in mestizo America: the cases of Mexico and Peru." Latino Research Review 7.1/2 (2009): 30-58

Sulmont, David, and Néstor Valdivia. 2012. "From Pre-modern 'Indians' to Contemporary 'Indigenous People': Race and Ethnicity in Peruvian Censuses, 1827-2007." Pp. 185-200 in Everlasting Countdowns: Race, Ethnicity and National Censuses in Latin American States.

Sulmont, David, and Juan Carlos Callirgos. 2014. “¿El País de todas las Sangres? Race and Ethnicity in Contemporary Peru." Pp. 126-171 in Pigmentocracies: Ethnicity, Race, and Color in Latin America, edited by Edward Telles. University of North Carolina Press

Telles, Edward and Nelson Lim. 1998. "Does it matter who answers the race question? Racial classification and income inequality in Brazil." Demography 35.4: 465-474.

Telles, Edward, and Denia Garcia. 2013. "Mestizaje and public opinion in Latin America." Latin American Research Review 48.3: 130-152.

Telles, Edward, Flores, Rene D., \& Fernando Urrea-Giraldo. 2015. “Pigmentocracies: Educational Inequality, Skin Color and Census Ethnoracial Identification in Eight Latin American Countries" Research in Social Stratification and Mobility.

Telles, Edward and Project on Ethnicity and Race in Latin America (PERLA). 2014. Pigmentocracies: Ethnicity, Race and Color in Latin America. University of North Carolina Press.

Telles, Edward, and Tianna Paschel. 2014."Who Is Black, White, or Mixed Race? How Skin Color, Status, and Nation Shape Racial Classification in Latin America1." American Journal of Sociology 120.3: 864-907.

Torche, Florencia, and Seymour Spilerman. 2009. "Intergenerational influences of wealth in Mexico." Latin American Research Review 44.3: 75-101.

Vermunt, Jeroen, and Jay Magidson. 2000. “Latent GOLD’s User's Guide.” Statistical Innovations Inc.

Villarreal, Andres. 2014. "Ethnic Identification and Its Consequences for Measuring Inequality in Mexico." American Sociological Review 79.4 (2014): 775-806.

Wade, Peter. 1997. Race and ethnicity in Latin America. Pluto Press.

Walsh, Michael. 2005. "Will Indigenous languages survive?" Annual Rev. Anthropology. 34: 293-315.

Wasserstrom, Robert. 1983. Class and Society in Central Chiapas. Berkeley and Los Angeles: University of California Press.

Waters, Mary C. 1990. Ethnic options: Choosing identities in America. Univ of California Press.

Wimmer, Andreas. 2013. Ethnic Boundary Making: Institutions, Power, Networks. Oxford University Press.

Weaver, Hilary N. 2001 "Indigenous Identity: What Is It and Who Really Has It?" American Indian Quarterly 25(2): 240-255. 
Yashar, Deborah. 2005. Contesting Citizenship in Latin America: The Rise of Indigenous Movement and the Postliberal Challenge. Cambridge University Press. 
Table 1. Percent Size of Indigenous Population in Mexico and Peru using Alternative Measures

\begin{tabular}{lll}
\hline & MEXICO & PERU \\
\hline A. Self-Identification in an Indigenous Ethnic Group based on ancestors and customs & & \\
1 & 22.2 & 23.5 \\
B. Self-Identification as "Indigenous" using five mutually-exclusive categories ${ }^{2}$ & 12.4 & 4.7 \\
C. Speaking Fluency in Indigenous Language & 16.2 & 23.4 \\
D. Interviewer Classification as Indigenous using five mutually-exclusive categories ${ }^{2}$ & 8.8 & 6.3 \\
E. Indigenous First Language & 12.5 & 11.4 \\
F. Some ability to understand Indigenous language & 20.9 & 42.5 \\
G. Indigenous mother 3 & 16.7 & 31.7 \\
H. Indigenous father ${ }^{3}$ & 16.5 & 29 \\
I. Mother Speaks/Spoke Indigenous Language & 15.2 & 38.4 \\
J. Father Speaks/Spoke Indigenous Language & 16.1 & 36.8 \\
K. At least one parent Speaks/Spoke Indigenous Language & 18.2 & 42.7 \\
L. At least one Grandparent Speaks/Spoke Indigenous Language & 27.6 & 49.8 \\
\hline
\end{tabular}

Source: 2010 PERLA Nationally Representative Sample Surveys of Mexico and Peru

1 "Based on your ancestors or customs, do you consider yourself of [list of specific indigenous groups, blacks, white, mulata, mestiza, other] origin?." Indigenous ethnic groups included in the Mexican case are: Náhuatl, Maya, Zapoteco, Mixteco, and other indigenous group. In the Peruvian case they are: Quechua, Aymara, and Amazonic.

2 "Do you consider yourself to be mulata, black, indigenous, mestiza, white, or other?"

3 This item used item A formulation in Peru and item B formulation in Mexico. 
Table 2. Fit statistics of latent class analysis of eight indicators of indigeneity with different numbers of latent classes.

\begin{tabular}{lcccccccccc}
\hline & \multicolumn{1}{c}{ Mexico } & \multicolumn{1}{c}{ Peru } \\
\hline $\begin{array}{l}\text { Number or latent } \\
\text { classes: }\end{array}$ & 1 class & 2 & 3 & 4 & 5 & 1 class & 2 & 3 & 4 \\
Likelihood-Ratio & 4343.0 & 533.5 & 307.1 & 151.3 & 119.1 & 2663.5 & 508.2 & 273.0 & 140.0 & 91.4 \\
degrees of freedom & 120 & 112 & 104 & 96 & 88 & 120 & 112 & 104 & 96 & 88 \\
p-value & 0 & 0 & 0 & .0003 & .02 & 0 & 0 & 0 & .002 & .38 \\
BIC $^{1}$ & 3485.8 & -266.4 & -435.7 & -534.4 & -509.4 & 1788.6 & -308.4 & -485.2 & -559.9 & -550.2 \\
AIC $^{2}$ & 4103.0 & 309.5 & 99.1 & -40.7 & -56.8 & 2423.5 & 284.2 & 65.0 & -52.0 & -84.6 \\
\hline
\end{tabular}

1 Bayesian Information Criterion

2 Akaike Information Criterion 
Table 3. Probability of identifying as indigenous based on different indicators conditional on ethnic type class membership, and proportion of the population in ethnic type.

\begin{tabular}{|c|c|c|c|c|}
\hline Ethnic Type & $\begin{array}{c}\text { Indigenous } \\
\text { Mestizos }\end{array}$ & $\begin{array}{l}\text { New } \\
\text { Indians }\end{array}$ & $\begin{array}{l}\text { Traditional } \\
\text { Indians }\end{array}$ & $\begin{array}{c}\text { Non- } \\
\text { Indigenous }\end{array}$ \\
\hline \multicolumn{5}{|l|}{ Mexico: } \\
\hline \multicolumn{5}{|l|}{ Conditional probability of: } \\
\hline $\begin{array}{l}\text { 1. Self-Identification in an indigenous ethnic group based on } \\
\text { ancestors and customs }\end{array}$ & 0.747 & 0.571 & 0.985 & 0.114 \\
\hline $\begin{array}{l}\text { 2. Self-Identification as "Indigenous" using five mutually- } \\
\text { exclusive categories }\end{array}$ & 0.123 & 0.429 & 0.853 & 0.001 \\
\hline 3. Interviewer identification as indigenous & 0.230 & 0.205 & 0.656 & 0.019 \\
\hline 4. Indigenous first language & 0.731 & 0.056 & 0.912 & 0.021 \\
\hline 5. Understand indigenous language & 0.989 & 0.285 & 0.980 & 0.100 \\
\hline 6. Both parents are/were indigenous & 0.088 & 0.564 & 0.907 & 0.021 \\
\hline 7. Both parents speak/spoke indigenous language & 0.888 & 0.217 & 0.982 & 0.027 \\
\hline Relative size (model-based, main sample) & $6.4 \%$ & $7.6 \%$ & $7.3 \%$ & $78.8 \%$ \\
\hline Relative size (model-based, includes indigenous oversample) & $12.1 \%$ & $9.7 \%$ & $24.9 \%$ & $53.4 \%$ \\
\hline \multicolumn{5}{|l|}{ Peru: } \\
\hline \multicolumn{5}{|l|}{ Conditional probability of: } \\
\hline $\begin{array}{l}\text { 1. Self-Identification in an indigenous ethnic group based on } \\
\text { ancestors and customs }\end{array}$ & 0.068 & 0.970 & 0.910 & 0.023 \\
\hline $\begin{array}{l}\text { 2. Self-Identification as "Indigenous" using five mutually- } \\
\text { exclusive categories }\end{array}$ & 0.008 & 0.087 & 0.257 & 0.001 \\
\hline 3. Interviewer identification as indigenous & 0.045 & 0.061 & 0.295 & 0.012 \\
\hline 4. Indigenous first language & 0.098 & 0.028 & 0.624 & 0.000 \\
\hline 5. Understand indigenous language & 0.898 & 0.454 & 0.998 & 0.154 \\
\hline 6. Both parents are/were indigenous & 0.307 & 0.708 & 0.931 & 0.024 \\
\hline 7. Both parents speak/spoke indigenous language & 0.817 & 0.284 & 0.984 & 0.038 \\
\hline Relative size (model-based) & $16.3 \%$ & $7.2 \%$ & $14.8 \%$ & $61.7 \%$ \\
\hline
\end{tabular}


Table 4. Multinomial Logit Model of Socio-Demographic Factors Related to Ethnic Type in Mexico and Peru.

\begin{tabular}{|c|c|c|c|c|c|c|c|c|}
\hline & \multicolumn{4}{|c|}{ Mexico } & \multicolumn{4}{|c|}{ Peru } \\
\hline & $\begin{array}{c}\text { Indigenous } \\
\text { mestizo }\end{array}$ & New Indian & $\begin{array}{l}\text { Traditional } \\
\text { Indian }\end{array}$ & $\begin{array}{c}\text { Non- } \\
\text { Indigenous }\end{array}$ & $\begin{array}{c}\text { Indigenous } \\
\text { mestizo }\end{array}$ & $\begin{array}{l}\text { New } \\
\text { Indian }\end{array}$ & $\begin{array}{l}\text { Traditional } \\
\text { Indian }\end{array}$ & $\begin{array}{c}\text { Non- } \\
\text { Indigenous }\end{array}$ \\
\hline Age & $\begin{array}{c}-0.019 * * * \\
(0.007)\end{array}$ & $\begin{array}{l}-0.015^{*} \\
(0.008)\end{array}$ & $\begin{array}{l}-0.009 \\
(0.006)\end{array}$ & & $\begin{array}{c}0.007 \\
(0.006)\end{array}$ & $\begin{array}{c}-0.024^{* *} \\
(0.009)\end{array}$ & $\begin{array}{c}0.006 \\
(0.006)\end{array}$ & \\
\hline Schooling & $\begin{array}{c}-0.062^{* *} \\
(0.027)\end{array}$ & $\begin{array}{l}-0.043 \\
(0.031)\end{array}$ & $\begin{array}{c}-0.086^{* * *} \\
(0.023)\end{array}$ & & $\begin{array}{c}-0.016 \\
(0.025)\end{array}$ & $\begin{array}{c}-0.018 \\
(0.038)\end{array}$ & $\begin{array}{c}-0.061^{* *} \\
(0.024)\end{array}$ & \\
\hline Urban residence & $\begin{array}{c}0.437^{*} \\
(0.240)\end{array}$ & $\begin{array}{c}0.260 \\
(0.273)\end{array}$ & $\begin{array}{c}0.014 \\
(0.179)\end{array}$ & & $\begin{array}{l}-0.339^{*} \\
(0.191)\end{array}$ & $\begin{array}{l}0.725^{* *} \\
(0.340)\end{array}$ & $\begin{array}{c}-0.236 \\
(0.182)\end{array}$ & \\
\hline Male & $\begin{array}{c}0.050 \\
(0.196)\end{array}$ & $\begin{array}{c}0.115 \\
(0.225)\end{array}$ & $\begin{array}{c}0.017 \\
(0.159)\end{array}$ & & $\begin{array}{c}-0.243 \\
(0.161)\end{array}$ & $\begin{array}{c}0.081 \\
(0.234)\end{array}$ & $\begin{array}{c}-0.062 \\
(0.158)\end{array}$ & \\
\hline Skin color & $\begin{array}{c}0.244^{* * *} \\
(0.072)\end{array}$ & $\begin{array}{c}0.111 \\
(0.086)\end{array}$ & $\begin{array}{c}0.356^{* * *} \\
(0.059)\end{array}$ & & $\begin{array}{c}0.155^{* * *} \\
(0.059)\end{array}$ & $\begin{array}{c}0.055 \\
(0.087)\end{array}$ & $\begin{array}{c}0.195^{* * *} \\
(0.058)\end{array}$ & \\
\hline Household SES & $\begin{array}{c}-0.634^{* * *} \\
(0.118)\end{array}$ & $\begin{array}{c}-0.555^{* * *} \\
(0.135)\end{array}$ & $\begin{array}{c}-1.130^{* * *} \\
(0.100)\end{array}$ & & $\begin{array}{c}-0.138 \\
(0.105)\end{array}$ & $\begin{array}{c}-0.346^{* *} \\
(0.152)\end{array}$ & $\begin{array}{c}-0.475^{* * *} \\
(0.106)\end{array}$ & \\
\hline Constant & $\begin{array}{c}-1.802^{* * *} \\
(0.573)\end{array}$ & $\begin{array}{c}-1.722^{* * *} \\
(0.658)\end{array}$ & $\begin{array}{c}-1.783^{* * *} \\
(0.464)\end{array}$ & & $\begin{array}{c}-1.974^{* * *} \\
(0.528)\end{array}$ & $\begin{array}{c}-2.294^{* * *} \\
(0.798)\end{array}$ & $\begin{array}{c}-1.857^{* * *} \\
(0.513)\end{array}$ & \\
\hline Observations & & & & & & & 440 & \\
\hline
\end{tabular}

Standard errors in parentheses ${ }^{*} \mathrm{p}<.10,{ }^{* *} \mathrm{p}<.05,{ }^{* * *} \mathrm{p}<.01$ 
Table 5. Ordered Logit Model Predicting Attitudes of Non-Indigenous, Traditional Indians and Indigenous Mestizos compared to New Indians (reference category) in Mexico and Peru with controls for age, education, urban residence, sex, skin color and household assets.

\begin{tabular}{|c|c|c|c|c|c|c|}
\hline & Mestizaje $^{1}$ & $\begin{array}{c}\text { Indigenous } \\
\text { Organization }{ }^{2}\end{array}$ & $\begin{array}{c}\text { Systemic } \\
\text { Discrimination }^{3} \\
\end{array}$ & Ethnic Conflict ${ }^{4}$ & $\begin{array}{c}\text { Witnessed } \\
\text { Discrimination }^{5}\end{array}$ & $\begin{array}{c}\text { Personal } \\
\text { Discrimination }^{6}\end{array}$ \\
\hline \multicolumn{7}{|l|}{ Mexico: } \\
\hline Traditional & 0.123 & $0.703^{* * *}$ & -0.108 & 0.149 & $0.641^{* * *}$ & $0.819^{* * *}$ \\
\hline Indians & $(0.190)$ & $(0.178)$ & $(0.167)$ & $(0.150)$ & $(0.147)$ & $(0.180)$ \\
\hline Indigenous & $0.488^{*}$ & $0.859 * * *$ & $-0.370^{*}$ & 0.234 & $0.565^{* * *}$ & -0.024 \\
\hline Mestizos & $(0.260)$ & $(0.237)$ & $(0.209)$ & $(0.187)$ & $(0.178)$ & $(0.248)$ \\
\hline \multirow[t]{2}{*}{ New Indians } & -0.233 & $0.413^{*}$ & $0.597^{* *}$ & $0.692^{* * *}$ & 0.267 & 0.276 \\
\hline & $(0.243)$ & $(0.247)$ & $(0.271)$ & $(0.214)$ & $(0.214)$ & $(0.268)$ \\
\hline \multicolumn{7}{|l|}{ Peru: } \\
\hline Traditional & $-0.472^{* * *}$ & -0.222 & -0.037 & 0.242 & $0.800^{* * *}$ & $0.828^{* * *}$ \\
\hline Indians & $(0.168)$ & $(0.177)$ & $(0.174)$ & $(0.148)$ & $(0.142)$ & $(0.163)$ \\
\hline Indigenous & -0.022 & 0.222 & -0.250 & -0.181 & $0.426^{* * *}$ & $0.434^{* *}$ \\
\hline Mestizos & $(0.183)$ & $(0.190)$ & $(0.173)$ & $(0.149)$ & $(0.144)$ & $(0.176)$ \\
\hline \multirow[t]{2}{*}{ New Indians } & $-0.424^{*}$ & 0.323 & 0.134 & 0.013 & $0.387^{*}$ & 0.176 \\
\hline & $(0.247)$ & $(0.282)$ & $(0.267)$ & $(0.220)$ & $(0.207)$ & $(0.260)$ \\
\hline \\
\hline \multicolumn{7}{|c|}{1 "Intermixing of people with different origins/races is good for the country" (Mestizaje) } \\
\hline \multicolumn{7}{|c|}{2 "I agree with indigenous political organizations that seek to reclaim indigenous rights" (Indigenous Organization) } \\
\hline \multicolumn{7}{|c|}{3 "In this country, are indigenous people treated better, the same, or worse than whites?" (Systemic Discrimination) } \\
\hline \multicolumn{7}{|c|}{4 "In this country, there is a lot, some, a little, or no conflict between indigenous and whites" (Ethnic Conflict) } \\
\hline \\
\hline \multicolumn{7}{|c|}{6 "I have felt discriminated against because of my accent or the way I speak" (Personal Discrimination) } \\
\hline
\end{tabular}




\section{Endnotes:}

${ }^{1}$ In Mexico, Data: Opinión Pública y Mercado and in Peru, IPSOS.

${ }^{2}$ Note that the parameter estimates of non-linear models such as the MNL model cannot be directly compared across countries. The reason is that the comparison across groups relies on the assumption that the error variance is the same across groups. If this assumption is violated, comparisons are meaningless (Hoetker 2004). As such, we comment on the sign and statistical significance of the parameter estimates across countries but do not offer a formal comparison of their magnitude. 